\title{
Essential or Expendable Supports? Assessing the Relationship between School Climate and Student Outcomes
}

\author{
Joshua Klugman
}

Temple University

Abstract: Sociologists of education argue that school organizational practices and climates influence students' academic outcomes. The predominant measure of school climates are aggregated student and teacher survey reports, which are diffusing into official educational statistics. Unfortunately, most studies are unable to rigorously assess the causal effects of these measures of school organization. This study does so by examining the effects of school climate experienced in grades 4- 8 by different cohorts of students in Chicago Public Schools (CPS). Improvement in school climates has small positive associations with students' eighth grade test scores and null to minimal associations with students' chances of on-time ninth grade promotion and high school graduation.

Keywords: school climate; school effects; graduation; test scores; organizational practices

Citation: Klugman, Joshua. 2016. "Essential or Expendable Supports? Assessing the Relationship between School Climate and Student Outcomes." Sociological Science 4: 31-53.

Received: September 10, 2016

Accepted: October 1, 2016

Published: January 10, 2017

Editor(s): Jesper Sørensen, Stephen Morgan

DOI: $10.15195 / \mathrm{v} 4 . \mathrm{a} 2$

Copyright: (C) 2017 The Author(s). This open-access article has been published under a Creative Commons Attribution License, which allows unrestricted use, distribution and reproduction, in any form, as long as the original author and source have been credited. (0)(1)
$\mathrm{W}$

HAT makes a school good? Since the Coleman report (1966), educational researchers have searched for school qualities benefitting students. As Gamoran, Secada, and Marrett (2000) noted, mixed findings have frustrated these efforts, with ambiguous evidence for effects of material resources (Burtless 1996; Grubb 2009; but see Jackson, Johnson, and Persico 2016) and student composition (e.g., Gamoran 1987; Gamoran, Collares, and Barfels 2016; Lauen and Gaddis 2013). Consequently, many researchers have tried to unpack the "black box" of school effects by outlining the organizational practices leading to improved student outcomes (Gamoran et al. 2000), raising the possibility that best practices can be disseminated across schools.

Researchers use survey reports of school personnel and students to measure school organizational practices and climates. Schools where teachers report having effective principals and colleagues who take their professional roles seriously and where students report having positive relationships with teachers and learning environments free of disruption have better student outcomes and smaller inequalities in outcomes (e.g., Bodovski, Nahum-Shani, and Walsh 2013; Bryk et al. 2010; Kraft, Marinell, and Yee 2016; Moller et al. 2013). The notion of school climate is sociologically appealing. While proponents of this approach appreciate the crucial "technical core" of instruction, they draw attention to instructional quality's dependence on relationships among school actors: administrators, teachers, students, and parents (Bryk and Schneider 2002; Bryk et al. 2010).

The idea that school climate is important and quantifiable is not limited to sociologically-minded educational researchers-educational agencies are relying more and more on climate surveys. They are used in public reports on school or district quality in school districts in the United States such as Boston, Madison, 
New York City, and Seattle. School climate surveys are also used statewide in California, Georgia, and Illinois (among others). When the U.S. Congress renewed the Elementary and Secondary Education Act in 2015, it mandated that states incorporate nonacademic factors into their accountability systems, which in all likelihood will lead to the spread of punitive measures for schools lacking positive school climates (Blad 2016), as they are in Chicago. Moreover, a school climate industry has sprouted, with organizations such as the National School Climate Center, Panorama, and UChicago-Impact selling survey services to school systems.

Unfortunately, the collective research base cannot justify this expansion of school climate surveys. Findings on the effectiveness of school climate differ, with some studies finding either minimal or no associations (e.g., Ladd 2009; Phillips 1997) while others find very strong positive ones (e.g., Goddard et al. 2015; Moller et al., 2013). To varying degrees, these studies suffer from limited measures and limited ability to identify the causal effects of attending a school with a strong climate. Recent research has made headway on these problems (Bryk et al. 2010; Kraft et al. 2016; Moller et al. 2013), but shares a focus on student achievement on standardized scores; we know little about the effects of school climate on other (arguably more important) outcomes, such as educational transitions and high school graduation.

This study uses longitudinal data on public elementary schools in Chicago collected over a 14-year period using a rich data set of measures of school climate. This allows for more rigorous testing of the causal effects of school climate by comparing cohorts of students who attended the same school and experienced different school climates. The longitudinal data also allows for examination of not just students' tested achievement but also less-studied outcomes such as on-time promotion to high school and high school graduation.

\section{Background}

Prior scholarship has emphasized eclectic, diverse, and overlapping sets of characteristics of schools' organizational climates. Syntheses by researchers at the University of Chicago Consortium on School Research (Bryk et al. 2010; Sebring et al. 2006) have been influential in drawing together disparate strands of work on school leadership, teacher professional communities, and student learning conditions. Their "essential supports" framework has seen principals as the prime movers in school improvement. Drawing on the concepts of instructional and transformational leadership (Hallinger, Bickman, and Davis 1996; Hitt and Tucker 2016; Marks and Printy 2003), Bryk and colleagues emphasized the importance of principals having a clear vision for the school, implementing high instructional standards, making sure that instruction is organized across subjects and grade levels to avoid redundancy in what students learn, providing teachers with opportunities for professional development, and fostering teacher buy-in into school improvement efforts by giving them a voice in school policies (especially over instructional and curricular matters).

For a principal to succeed in upholding high instructional standards and an organized, coherent curriculum, he or she needs to inspire teachers to embrace their roles as professionals. Sociologists have argued that the ideal school organization 
is communal (Lee and Smith 1993), in which teachers are willing to go above and beyond their contractual obligations and assume the responsibilities to help students learn, work with other teachers to adopt new instructional techniques, coordinate the curriculum and student assessments, and enforce rules (Bryk and Schneider 2002; Goddard et al. 2015; Moller et al. 2013). Ideally, these collective efforts, inspired by the principal, will translate into optimal pedagogy in the classroom, student engagement, and minimal disruptive behavior.

Estimated associations between school climate and student outcomes have varied across studies, and there are no clear methodological differences that explain this variation. Those with rich measures of school climate have reported no associations (Phillips 1997), modest positive ones (Johnson, Kraft, and Papay 2012; Kraft et al. 2016; Ladd 2009; Sebastian and Allensworth 2012), or very strong positive ones (Bryk et al. 2010; Goddard et al. 2015; Hallinger and Heck 2010; Ronfeldt et al. 2015). Even if attention is confined to just those showing positive effects, they suffer from shortcomings that prevent a clear conclusion that school climate matters.

First, work in this area has just started to grapple with the issue of causal inference; most studies have relied on cross-sectional associations between school climate measures and student outcomes, controlling for observed characteristics such as prior tested achievement (Goddard et al. 2015; Johnson et al. 2012; Ladd 2009; Ronfeldt et al. 2015; Sebastian and Allensworth 2012). The obvious problem with this approach is that of unobserved heterogeneity; schools with strong climates may have better student outcomes for reasons other than their climates which are not observed with control variables (including prior achievement). One likely possibility is selection bias-students predisposed to doing well academically are drawn to schools with strong climates. Teacher and student reports on school climates may be influenced by a general sense of how well the school is doing, which in turn may be colored by the academic abilities of students (Pallas 1988).

Only recently have scholars used longitudinal data on schools covering multiple cohorts of students and isolating intraschool, over-time variation in climates to study student annual gains in learning (Bryk et al., 2010:250-251; Kraft et al. 2016). They generally find small but statistically significant positive effects of measures tapping into instructional leadership and safety, with mixed results for measures of teacher collaboration and professional community. Kraft et al. (2016) argue that these effects, small as they are, are sufficiently big to the justify the use of school climate data by educators and policymakers because small effects in annual learning accumulate into big effects over time.

The second issue with school climate research is that most studies take this assumption for granted - that affecting annual (or sometimes biannual) learning gains is sufficient (Bodovski, Nahum-Shani, and Walsh 2013; Goddard et al. 2015; Hallinger and Heck 2010; Heck and Hallinger 2009; Johnson et al. 2012; Ladd 2009; Ronfeldt et al. 2015; Sebastian and Allensworth 2012). Very few studies look at other (arguably more consequential) outcomes, such as accumulated learning over a longer time period or high school graduation. This is a striking omission, given that what matters for longer-term student outcomes may not matter for test scores and vice versa (Heckman, Pinto, and Savelyev 2014; Jackson 2012; Jennings et al. 2015). The few studies looking at educational transitions-high school graduation 
or dropping out - tend to find modest or null effects of school climate (Bryk and Thum 1989; Kotok, Ikoma, and Bodovski 2016; Reed 2015; Rumberger and Thomas 2000). However, they are hampered by a reliance on National Center for Education Statistics (NCES) data sets, which have a limited measures of school climates, both in terms of using small samples of students and teachers to characterize an entire school and in terms of using survey questions superficially covering the aspects of climate thought to matter for school success.

In terms of accumulated learning, Moller and colleagues (2013) estimated associations with school climate and found that for black and Latino students as well as low-SES students, there are large benefits of attending schools with strong collaborative teacher communities. While this work has been useful for examining accumulated exposure to school climates, it suffers from previously mentioned shortcomings: because the authors used a NCES data set (the Early Childhood Longitudinal Study-Kindergarten cohort of 1998), they are forced to rely on sparse measures of school climate and are unable to speak to how school improvement on climate matters for student outcomes. Moreover, this study has limited school-level controls (there are no controls for school aggregates of prior tested ability and SES), raising the possibility that its strong climate effects are artifacts of unobserved heterogeneity.

This study's innovation is in combining the methodological and substantive strengths of prior work while avoiding various weaknesses. Using survey reports of most students and teachers in Chicago schools, I measure various aspects of school climate. Using longitudinal data and a specification analogous to school fixed effects models, I am able to isolate the over-time, intraschool associations between climate and student outcomes. Like Moller et al. (2013), I look at how accumulated exposure to school climates matter for student outcomes, but I go beyond accumulated learning and also examine educational transitions.

\section{Data and Methods}

The district collects annual data on all Chicago Public Schools (CPS) students' school status, demographics, and test scores and transmits them to the University of Chicago Consortium on School Research. In the early 1990s, the district, in collaboration with the Consortium (then known as the Consortium on Chicago School Research, or CCSR) fielded surveys in which students (grades 6-12) and teachers would report on various aspects of their schools' organizational, instructional, social, and academic climates. ${ }^{1}$ By the spring 1997 administration, the Consortium had introduced all survey measures used in this article and began administrating the survey on a biannual basis; in 2011, the district switched to an annual administration, although for the sake of consistency this study will only use data from the odd-numbered spring years. In the data used in this study, the student response rates ranged from 0.19 to 1.00 , with a median value of 0.83 (interquartile range $=$ $0.75-0.89$ ), and teacher response rates ranged from 0.03 to 1.00 , with a median value of 0.68 (interquartile range $=0.54-0.81$ ). These response rates are similar to those in the initial year in the New York City data Kraft et al. (2016) used, although in New York, response rates grew over time, whereas in Chicago there is no global trend. 
The population frame consists of students who were first-time third graders in the 1995-1996, 1997-1998, 1999-2000, 2001-2002, 2003-2004, and 2005-2006 school years, remained in CPS, and attended the same school in their fourth, sixth, and eighth years. For the sake of convenience, the first, third, and fifth years after being a third grader are referred to as the students' fourth, sixth, and eighth years, respectively. For outcomes related to on-time educational transitions (ninth grade promotion and high school graduation), the sample excludes students who were retained in third grade in their fourth year because it would be virtually impossible for schools to ensure timely educational transitions for such students. Because most elementary schools in CPS have a K-8 grade configuration (only a handful have a $\mathrm{K}-5$ or $6-8$ configuration), these measures will capture the school climates students experienced throughout their primary grade years. Table 1 shows the total number of observations and survey years for each cohort of first-time third graders.

This population frame was selected for a couple of reasons. First, because CPS students begin testing in the third grade, selecting first-time third graders allows for the controlling of student tested ability measured before they experience their school climates in their fourth, sixth, and eighth years. Second, the cohorts stop at 2005-2006 to allow for the measurement of on-time high school graduation. This choice also has the benefit of minimizing the use of school climates measured during and after the 2010-2011 school year, when school results were made public (which possibly affected teachers' answers). Third, students who attended the same school in their fourth, sixth, and eighth years were selected to isolate intraschool variation in school climates. In an alternative specification presented in the supplement, this requirement will be relaxed, at the cost of allowing for interschool variation in school climates.

\section{Outcomes}

I analyze four student outcomes. Graduation is an indicator if the student graduated from a CPS high school nine years years after being a first-time third grader; ontime ninth grade promotion is an indicator if the student was in the ninth grade six years after being a first-time third grader; math and reading eighth-grade scores are scores from standardized tests given to students in the spring of their eighth grade year, which could be the Iowa Test of Basic Skills (ITBS), the original version of the Illinois Standards Achievement Test (ISAT), and a revised version of the ISAT produced in response to No Child Left Behind (NCLB). Scores on these tests were standardized by grade level and test; students who took multiple tests had their scores averaged. ${ }^{2}$ Summary statistics on these outcomes, as well as predictors used in this analysis, are presented in Table 2. Note that z-standardization for test scores and other variables was done for the entire CPS population, but the mean values presented in Table 2 are substantially different from zero, reflecting the fact that analyses are restricted to students who remained in the same school in their fourth, sixth, and eighth years. 
Table 1: Third-grade cohorts used in analyses.

\begin{tabular}{ccccc}
\hline \multirow{2}{*}{$\begin{array}{c}\text { Cohort } \\
\text { (year in third grade) }\end{array}$} & $\mathrm{N}$ & \multicolumn{3}{c}{ Survey Years } \\
\cline { 3 - 5 } & 10,710 & Fourth Year & Sixth Year & Eighth Year \\
\hline $1995-1996$ & 11,067 & $1996-97$ & $1998-99$ & $2000-01$ \\
$1997-1998$ & 11,689 & $2000-01$ & $2000-01$ & $2002-03$ \\
$1999-2000$ & 12,483 & $2002-03$ & $2002-03$ & $2004-05$ \\
$2001-2002$ & 13,253 & $2004-05$ & $2004-05$ & $2006-07$ \\
$2003-2004$ & 13,523 & $2006-07$ & $2006-07$ & $2008-09$ \\
$2005-2006$ & $2008-09$ & $2010-11$ \\
\hline
\end{tabular}

Notes: Climate surveys were conducted in the spring. N's refer to number of students included in analyses of eighth grade test scores, on-time ninth grade promotion, or high school graduation.

\section{School Climate}

For the 1997-2013 period, the Consortium has comparable estimates of 16 different aspects of school organizational climate; 11 are from the teacher surveys and five are from the student surveys. Each of these measures are listed in Table 3, along with a representative question (each measure is based on at least four different survey questions). I constructed three different "omnibus" measures: an overall climate measure (Cronbach's alpha $=0.91$ ) that is the average of all measures, an average teacher climate measure (Cronbach's alpha $=0.91$ ), and an average student climate measure (Cronbach's alpha $=0.72) .{ }^{3}$

The Consortium was thorough and careful in developing and refining these measures, informed by the essential supports framework. A Consortium psychometrician used Rasch analysis (Bond and Fox 2015) to test the appropriateness of these measures from earlier survey administrations (in 1991 and 1994) and to guide their further refinement. Rasch analysis estimates a difficulty level for each item (the fewer respondents endorsing an item, the more "difficult" it is) and an ability level for each respondent (the more respondents endorse items, particularly difficult ones, the higher his or her "ability" is). Measures based on items that can separate respondents based on ability have higher reliability. This approach is more sophisticated than common data reduction techniques used by sociologists (i.e., summed scales and factor analysis) because it forces analysts to grapple with the problem of being able to distinguish a wide range of respondent abilities. An additional advantage of Rasch measures is that measurement can change over time (items can be added or removed), but the estimates are comparable over time.

Within each year, school climate measures are constructed by aggregating all individual-level measures at the school level (each individual-level measure is weighted by the inverse of its standard error, such that individuals with more reliable measures are weighted more). ${ }^{4}$ For each student, a school climate measure was constructed by averaging their climate observations in their fourth, sixth, and 
Table 2: Summary statistics of all variables used in analyses.

\begin{tabular}{|c|c|c|c|c|c|c|}
\hline & & & Cohort & & & \\
\hline & 1996 & 1998 & 2000 & 2002 & 2004 & 2006 \\
\hline Outcomes & & & & & & \\
\hline Ninth Grade Promotion & 0.83 & 0.87 & 0.83 & 0.90 & 0.89 & 0.91 \\
\hline Eighth Grade Math Scores (z) & 0.20 & 0.28 & 0.20 & -0.03 & 0.06 & 0.25 \\
\hline ITBS & 0.34 & 0.35 & 0.22 & - & - & - \\
\hline Pre-NCLB ISAT & 0.05 & 0.21 & 0.19 & - & - & - \\
\hline Post-NCLB ISAT & - & - & - & -0.03 & 0.06 & 0.25 \\
\hline Eighth Grade Reading Scores $(z)$ & 0.10 & 0.14 & 0.18 & 0.08 & 0.09 & 0.16 \\
\hline ITBS & 0.22 & 0.22 & 0.23 & - & - & - \\
\hline Pre-NCLB ISAT & -0.02 & 0.05 & 0.13 & - & - & - \\
\hline Post-NCLB ISAT & - & - & - & 0.08 & 0.09 & 0.16 \\
\hline Graduation & 0.59 & 0.65 & 0.64 & 0.69 & 0.76 & 0.79 \\
\hline School Climate Measures & & & & & & \\
\hline Overall Climate & -0.01 & 0.00 & 0.15 & 0.30 & 0.37 & 0.64 \\
\hline Student Climate & 0.07 & 0.24 & 0.44 & 0.22 & -0.14 & 0.17 \\
\hline Teacher Climate & -0.03 & -0.06 & 0.03 & 0.27 & 0.45 & 0.66 \\
\hline Controls-Student Level & & & & & & \\
\hline Male & 0.49 & 0.48 & 0.49 & 0.49 & 0.50 & 0.50 \\
\hline Race (omitted: Latino) & & & & & & \\
\hline Asian/White & 0.16 & 0.16 & 0.14 & 0.13 & 0.13 & 0.14 \\
\hline Black & 0.47 & 0.47 & 0.46 & 0.45 & 0.41 & 0.36 \\
\hline Latino & 0.36 & 0.37 & 0.40 & 0.41 & 0.44 & 0.48 \\
\hline Other/Missing Race & 0.00 & 0.00 & 0.00 & 0.01 & 0.01 & 0.01 \\
\hline FRPL Status (0-1) & 0.77 & 0.78 & 0.80 & 0.80 & 0.79 & 0.78 \\
\hline Neighborhood Disadvantage $(z)$ & -0.10 & -0.09 & -0.08 & -0.07 & -0.10 & -0.14 \\
\hline Neighborhood Advantage $(z)$ & 0.08 & 0.06 & 0.01 & 0.01 & -0.01 & 0.00 \\
\hline Bilingual Education Status & 0.29 & 0.30 & 0.32 & 0.32 & 0.42 & 0.40 \\
\hline Third Grade Test Scores $(z)$ & 0.00 & 0.22 & 0.11 & 0.26 & 0.33 & -0.03 \\
\hline Third Grade Math Test Scores $(z)$ & 0.00 & 0.24 & 0.13 & 0.29 & 0.37 & -0.04 \\
\hline Third Grade Reading Test Scores $(z)$ & 0.00 & 0.21 & 0.09 & 0.24 & 0.29 & -0.02 \\
\hline Age in Third Grade & 8.86 & 8.86 & 8.90 & 8.90 & 8.90 & 8.89 \\
\hline Controls-School Level & & & & & & \\
\hline Prop Asian/White & 0.19 & 0.18 & 0.17 & 0.16 & 0.17 & 0.16 \\
\hline Prop Black & 0.55 & 0.54 & 0.55 & 0.55 & 0.55 & 0.55 \\
\hline Prop Other/Missing & 0.00 & 0.00 & 0.00 & 0.00 & 0.00 & 0.00 \\
\hline Average FRPL Status & 0.79 & 0.79 & 0.76 & 0.77 & 0.77 & 0.81 \\
\hline Average Neighborhood Disadvantage $(z)$ & -0.11 & -0.10 & -0.07 & -0.03 & 0.00 & 0.02 \\
\hline Average Neighborhood Advantage (z) & 0.07 & 0.06 & 0.07 & 0.06 & 0.06 & 0.07 \\
\hline Log Enrollment & 6.99 & 7.09 & 7.15 & 7.15 & 7.19 & 7.21 \\
\hline Proportion Years in Charter School & 0.00 & 0.00 & 0.01 & 0.02 & 0.01 & 0.03 \\
\hline
\end{tabular}


Table 3: Description of school climate measures.

\begin{tabular}{|c|c|}
\hline Average Measures & Description \\
\hline Overall Climate Measure & Average of 16 teacher and student measures \\
\hline Teacher Climate Measure & Average of 11 teacher measures \\
\hline Student Climate Measure & Average of five student measures \\
\hline Teacher-Reported Measures & Representative Question \\
\hline Collective Responsibility & $\begin{array}{l}\text { How many teachers in this school feel responsible when students in } \\
\text { this school fail? }\end{array}$ \\
\hline Teacher Influence & $\begin{array}{l}\text { How much influence do teachers have over establishing the curricu- } \\
\text { lum and instructional program? }\end{array}$ \\
\hline Innovation & $\begin{array}{l}\text { In this school, teachers are continually learning and seeking new } \\
\text { ideas }\end{array}$ \\
\hline Instructional Leadership & The principal at this school sets high standards for student learning \\
\hline Program Coherence & $\begin{array}{l}\text { There is consistency in curriculum, instruction, and learning materials } \\
\text { among teachers in the same grade level at this school }\end{array}$ \\
\hline Quality Professional Development & $\begin{array}{l}\text { Overall, my professional development experiences have been sus- } \\
\text { tained and coherently focused, rather than short-term and unrelated }\end{array}$ \\
\hline Reflective Dialogue & $\begin{array}{l}\text { This school year, how often have you had conversations with col- } \\
\text { leagues about what helps students learn best }\end{array}$ \\
\hline School Commitment & I feel loyal to this school \\
\hline Teacher-Parent Trust & Parents have confidence in the expertise of the teachers \\
\hline Teacher-Principal Trust & The principal has confidence in the expertise of the teachers \\
\hline Teacher-Teacher Trust & $\begin{array}{l}\text { Teachers at this school respect those colleagues who are expert at } \\
\text { their craft }\end{array}$ \\
\hline Student-Reported Measures & Representative Question \\
\hline Academic Engagement & Sometimes I get so interested in $\mathrm{m}$ \\
\hline Academic Personalism & $\begin{array}{l}\text { In my math class my teacher notices if I have trouble learning some- } \\
\text { thing }\end{array}$ \\
\hline Safety & How safe do you feel in the hallways and bathrooms of the school? \\
\hline Teacher-S & My teachers always keep their promises \\
\hline Peer Relationships & Most students in my school like to put others down \\
\hline
\end{tabular}

eighth years in CPS. For a student whose school participated in the survey all three years, his or her measure would be constructed thusly:

$$
\text { measure }_{j c}=\frac{\text { measure }_{j t=c+1}+\text { measure }_{j t=c+3}+\text { measure }_{j t=c+5}}{3}
$$

where $j$ indexes the school the student attended in his or her fourth, sixth, and eighth years, $c$ indexes his or her cohort (the year he or she was a first-time third grader), and $t$ indexes the year a school's measure comes from. For example, measure $e_{t=c+3}$ is a school climate measure, aggregated from all individual responses in school $j$ three years after students in cohort $c$ were third graders (their sixth-year school). Students 
whose school participated in the survey only one time or zero times were dropped from the analysis. ${ }^{5}$ All of these measures are $z$-standardized at the school-cohort level.

\section{Student Controls}

To account for potential student selection into schools, I control for various student characteristics. Student FRPL status is the student's average free/reduced-price lunch status, coded 1 if the student received free lunches, 0.5 if the student received reduced-price lunches, and zero if the student received neither. Student neighborhood disadvantage is an index of the poverty rate and joblessness rate in the block group in which the student lived (these proportions were converted to logits and z-standardized). Student neighborhood advantage is the mean years of education of individuals living in the student's block group. All three of these socioeconomic status variables-FRPL status, neighborhood disadvantage, and neighborhood advantage - are averaged across all years in which the student was in the CPS system. Student race consists of dummy indicators for being black; Latino; white/Asian; and other/missing race, while student sex is a dummy indicator for being male. Bilingual education status is measured by whether or not the student ever received bilingual education services when he/she was in CPS. Age is the student's age in years on January 1st in the year in which the student was a first-time third grader. Linear and quadratic terms for age are entered into the models. Student third grade math and reading test scores are constructed the same as eighth grade scores (see footnote 2$)^{6}$

\section{School Controls}

To ensure that school climate is not confounded with other characteristics of schools, various time-varying demographic characteristics of schools are controlled for. School averages were constructed for FRPL status, neighborhood socioeconomic disadvantage, neighborhood socioeconomic advantage, and third grade math and reading scores. Other school-level controls include racial composition (proportion black; proportion Asian/white, and proportion other/missing), the natural log of enrollment size, and charter status. All school-level demographic variables are treated the same way as the school climate measures-the average of the student's fourth-year, sixth-year, and eighth-year observations is calculated.

\section{Analytic Strategy}

This study pools data on six cohorts of first-time third graders in CPS. Logistic regression was used to analyze the high school graduation and on-time ninth grade promotion outcomes; linear regression was used to analyze eighth grade test scores. For both kinds of models, a school random effect was added to reduce bias in estimates of standard errors and to increase the efficiency of parameter estimates (Raudenbush and Bryk 2002).

As previously mentioned, unobserved heterogeneity afflicts studies using observational data on school climates. As with most other studies, I cannot completely 
eliminate the problem of unobserved heterogeneity, but I attempt to minimize it by following the steps of Kraft et al. (2016) and running a model akin to adding a fixed effect for schools. By controlling for the school a student attends and leveraging only over-time, intraschool variation in school climates, I account for all time-invariant school characteristics and presumably most family- and student-level characteristics that lead students to select into particular schools. I will return to this point when I partition variation in school climates. Of course, even if selection bias could be completely removed, a fixed effects specification would not guarantee causal identification because a school fixed effects model would not account for time-varying, school-level unobserved variables.

Unfortunately, because sample sizes range from 50,000-70,000 cases, it was computationally impossible to run a fixed effects specification with logistic regressions. I get around this issue by using what is alternatively called the "hybrid" (Allison 2009) or "between-within" (Sjölander et al. 2013) method. This approach simulates a fixed effects model by running a random effects regression and centering all predictors on the school mean (as well as controlling for the school means themselves):

$$
\begin{aligned}
Y_{i j c}= & \left.\beta \text { measure }_{j c}-\overline{\text { measure }}_{j}\right)+\beta\left(\overline{\text { measure }}_{j}\right) \\
& +\sum \beta\left(X_{i j c}-\bar{X}_{j}\right)+\sum \beta\left(\bar{X}_{j}\right) \\
& +\sum \beta\left(W_{j c}-\bar{W}_{j}\right)+\sum \beta\left(\bar{W}_{j}\right) \\
& +U_{j}+e_{i j c}
\end{aligned}
$$

where outcome $Y$ for student $i$ in school $j$ and cohort $c$ is a function of her school's mean climate measure ( $\overline{\text { measure }_{j}}$ ), her school-cohort's deviation from the school mean $\left(\right.$ measure $_{j c}-$ measure $_{j}$ ), vectors of student-level variables $\boldsymbol{X}$ and school-cohortlevel variables $W$ (that are similarly partitioned into school means and deviations from the school mean), school random effect $U_{j}$, and a student-level error term $e_{i j c}$. The coefficient for the centered versions of school climate measures represent the fixed effects estimates and are the only result presented from the between-within model. ${ }^{7}$

\section{Variation among Schools and Variation among Cohorts within Schools}

A potential concern with this study's design is that differences (in either outcomes or school climates) among cohorts attending the same school is a poor source of variation. To address this concern, multilevel linear models were run to partition the variances of outcomes and school climates. ${ }^{8}$ For outcome measures, three-level models were run, with students nested in their school-cohorts that in turn were nested in their schools; for the climate measures, two-level models were run, with school-cohorts nested in schools. The results are presented in Table 4. "Unadjusted" standard deviations and intraclass correlations (ICCs) are presented from empty models with no predictors; "adjusted" statistics are also presented from models including all student-level controls (for the climate measures, these controls are aggregated at the school-cohort level). 
Table 4: Variance partitioning of outcomes and school climate measures.

\begin{tabular}{|c|c|c|c|c|c|c|c|c|}
\hline & \multicolumn{4}{|c|}{ Unadjusted ("Empty") Model (1) } & \multicolumn{4}{|c|}{ Adjusted Model (2) } \\
\hline & \multirow{2}{*}{\multicolumn{2}{|c|}{ School Level }} & \multirow{2}{*}{\multicolumn{2}{|c|}{$\begin{array}{c}\text { School-Cohort } \\
\text { Level }\end{array}$}} & \multirow{2}{*}{\multicolumn{2}{|c|}{ School Level }} & \multirow{2}{*}{\multicolumn{2}{|c|}{$\begin{array}{c}\text { School-Cohor } \\
\text { Level }\end{array}$}} \\
\hline & & & & & & & & \\
\hline & SD & ICC & SD & ICC & SD & ICC & $\mathrm{SD}$ & ICC \\
\hline \multicolumn{9}{|l|}{$\overline{\text { Outcomes }}$} \\
\hline Eighth Grade Math $(z)$ & 0.45 & 0.21 & 0.22 & 0.05 & 0.16 & 0.07 & 0.19 & 0.10 \\
\hline Eighth Grade Reading $(z)$ & 0.39 & 0.17 & 0.14 & 0.02 & 0.09 & 0.02 & 0.12 & 0.04 \\
\hline Ninth Grade Promotion & $3.1 \%$ & 0.01 & $6.0 \%$ & 0.03 & $2.3 \%$ & 0.00 & $5.0 \%$ & 0.02 \\
\hline Graduation & $9.8 \%$ & 0.05 & $8.4 \%$ & 0.03 & $4.5 \%$ & 0.01 & $4.5 \%$ & 0.01 \\
\hline \multicolumn{9}{|l|}{ Climate Measures (z) } \\
\hline Overall Climate & 0.93 & 0.66 & 0.67 & 0.34 & 0.76 & 0.60 & 0.62 & 0.40 \\
\hline Teacher Climate & 0.86 & 0.57 & 0.74 & 0.43 & 0.74 & 0.52 & 0.71 & 0.48 \\
\hline Student Climate & 0.90 & 0.62 & 0.70 & 0.38 & 0.75 & 0.58 & 0.64 & 0.42 \\
\hline
\end{tabular}

Notes: Outcome measures were analyzed in three-level multilevel linear models, with students nested in school-cohorts nested in schools. Climate measures were analyzed in two-level multilevel linear models, with school-cohorts nested in schools. The adjusted model controls for student sex, race, cohort, age at third grade, bilingual education status, FRPL status, neighborhood advantage, neighborhood disadvantage, and third grade test scores. For school climate measures, these were aggregated at the school-cohort level.

The main conclusion from Table 4 is that there is substantial variation among cohorts attending the same school, both in terms of outcomes and in terms of school climate. After adjusting for student characteristics, the standard deviation of cohorts from their school mean in terms of test scores is about 0.12 (for reading) and 0.19 (for math) SD units; for on-time ninth grade promotion and high school graduation, the standard deviation is about 5 percent; for school climates, the standard deviation hovers between 0.62 and 0.71 SD units.

The other conclusion from this variance partitioning exercise is that observed student characteristics steer students to schools with better and worse climates, as can be seen by the fact that inter-school variances in school climates are reduced by around a third after controlling for student characteristics (e.g., $\left[0.93^{2}-0.76^{2}\right]$ / $0.93^{2}=0.34$ ). This selection explains an overwhelming amount of school differences in student outcomes; after controlling for student characteristics, the school-level variances for eighth-grade math and reading scores decline by 90 percent (for math: $\left[0.45^{2}-0.16^{2}\right] / 0.45^{2}=0.87$; for reading: $\left.\left[0.39^{2}-0.09^{2}\right] / 0.39^{2}=0.94\right)$, for on-time ninth grade promotion rates by 44 percent $\left(\left[3.1 \%^{2}-2.3 \%{ }^{2}\right] / 3.1 \%{ }^{2}=0.44\right)$, and for high school graduation by 79 percent $\left.\left(9.8 \%^{2}-4.5 \%{ }^{2}\right] / 9.8 \%{ }^{2}=0.79\right)$.

However, this selection is not particularly responsive to over-time changes in school climates, as can be seen by the fact that intraschool, intercohort variances in school climates are reduced by only around 15 percent (e.g., $\left[0.67^{2}-0.62^{2}\right] / 0.67^{2}=$ $0.14)$ after controlling for student characteristics. And in turn, student characteristics explain substantially less of the intercohort variances in student outcomes: 23 
percent of eighth grade test scores (e.g., $\left[0.22^{2}-0.19^{2}\right] / 0.22^{2}=0.23$ ) and 30 percent of on-time ninth grade promotion $\left(\left[6.0 \%^{2}-5.0 \%{ }^{2}\right] / 6.0 \%{ }^{2}=0.30\right)$. High school graduation is a clear exception: student characteristics explain 71 percent $\left(\left[8.4 \%^{2}-4.5 \%^{2}\right] / 8.4 \%^{2}=0.71\right)$ of intercohort variance in this outcome. If we make the (admittedly untestable) assumption that unobserved characteristics affecting selection have similar distributions and effects as observed characteristics, then selection bias should be much less of a problem when examining the associations between within-school changes in school climate, on the one hand, and test scores and on-time ninth grade promotion on the other.

\section{Missing Values and Attrition}

The population frame of this study is all first-time third graders in CPS in 1995-1996, 1997-1998, 1999-2000, 2001-2002, 2003-2004, and 2005-2006. Table S.5 in the online supplement lists the total number of students potentially eligible to be in the study, the number of students dropped for various reasons, and the number of students who ended up in the sample.

Between 33 and 39 percent of first-time third graders are retained for analyses. The biggest cause of missing cases are students who stayed in CPS and have complete data but transferred to a different CPS school in their sixth or eighth year. Such students account for between 27-32 percent of first-time third graders. In an alternative specification (discussed in the online supplement), they are retained, and the results are similar to the main set presented in this paper. The second biggest cause of missing data are students who have missing outcomes, usually resulting from transferring out of CPS by the time the outcome was measured. Such cases account for 19-31 percent of first-time third grade students. Analyses of attrition (see Table S.6 in the online supplement) show that school climate itself has small and contradictory effects on attrition. Instead, the main causes of attrition are race and socioeconomic status. Asian/white students and students who come from non-poor families or advantaged neighborhoods are much more likely to transfer out of CPS. As will be seen, the associations between school climate and student outcomes are somewhat stronger for these groups, so it is possible there is some downward bias in the presented estimates of school climate. This bias should be minimal because these students constitute only a small share of CPS first-time third graders (5 percent spent zero years receiving free or reduced-price lunches; 12 percent are Asian or white).

The other sources of missing data account for only a small portion of first-time third graders. Less than 10 percent of students are deleted because their school participated in the surveys either not at all or only once, and 1 percent of students are deleted because of missing data on control variables. 
Table 5: Associations between student outcomes and school climate experienced in fourth, sixth, and eighth years on student outcomes.

\begin{tabular}{|c|c|c|c|c|c|c|c|c|}
\hline \multirow[b]{4}{*}{$\begin{array}{l}\text { Climate } \\
\text { Measure (z) }\end{array}$} & \multicolumn{2}{|c|}{$\begin{array}{l}\text { Ninth Grade } \\
\text { Promotion }\end{array}$} & \multicolumn{2}{|c|}{$\begin{array}{c}\text { Eighth Grade } \\
\text { Math }\end{array}$} & \multicolumn{2}{|c|}{$\begin{array}{l}\text { Eighth Grade } \\
\text { Reading }\end{array}$} & \multicolumn{2}{|c|}{ Graduation } \\
\hline & (1) & (2) & (3) & (4) & (5) & (6) & (7) & (8) \\
\hline & $\begin{array}{c}\text { Random } \\
\text { Effects }\end{array}$ & $\begin{array}{l}\text { Between- } \\
\text { Within }\end{array}$ & $\begin{array}{c}\text { Random } \\
\text { Effects }\end{array}$ & $\begin{array}{l}\text { Between- } \\
\text { Within }\end{array}$ & $\begin{array}{l}\text { Random } \\
\text { Effects }\end{array}$ & $\begin{array}{l}\text { Between- } \\
\text { Within }\end{array}$ & $\begin{array}{l}\text { Random } \\
\text { Effects }\end{array}$ & $\begin{array}{l}\text { Between- } \\
\text { Within }\end{array}$ \\
\hline & $\begin{array}{l}\text { Model } \\
\text { (AME) }\end{array}$ & $\begin{array}{l}\text { Model } \\
\text { (AME) }\end{array}$ & $\begin{array}{l}\text { Model } \\
\text { (beta) }\end{array}$ & $\begin{array}{c}\text { Model } \\
\text { (beta) }\end{array}$ & $\begin{array}{l}\text { Model } \\
\text { (beta) }\end{array}$ & $\begin{array}{l}\text { Model } \\
\text { (beta) }\end{array}$ & $\begin{array}{l}\text { Model } \\
\text { (AME) }\end{array}$ & $\begin{array}{l}\text { Model } \\
\text { (AME) }\end{array}$ \\
\hline Overall & $\begin{array}{l}0.00 \\
(0.002)\end{array}$ & $\begin{array}{l}0.00 \\
(0.003)\end{array}$ & $\begin{array}{c}0.04^{*} \\
(0.004)\end{array}$ & $\begin{array}{c}0.05^{*} \\
(0.004)\end{array}$ & $\begin{array}{l}0.03^{*} \\
(0.004)\end{array}$ & $\begin{array}{c}0.04^{*} \\
(0.005)\end{array}$ & $\begin{array}{l}0.00 \\
(0.003)\end{array}$ & $\begin{array}{c}0.01^{*} \\
(0.004)\end{array}$ \\
\hline Student & $\begin{array}{l}0.00 \\
(0.002)\end{array}$ & $\begin{array}{l}0.00 \\
(0.003)\end{array}$ & $\begin{array}{l}0.04^{*} \\
(0.004)\end{array}$ & $\begin{array}{l}0.05^{*} \\
(0.004)\end{array}$ & $\begin{array}{l}0.03^{*} \\
(0.004)\end{array}$ & $\begin{array}{c}0.03^{*} \\
(0.005)\end{array}$ & $\begin{array}{l}0.00 \\
(0.003)\end{array}$ & $\begin{array}{c}0.01^{*} \\
(0.004)\end{array}$ \\
\hline Teacher & $\begin{array}{c}0.00 \\
(0.002)\end{array}$ & $\begin{array}{l}0.00 \\
(0.003)\end{array}$ & $\begin{array}{l}0.04^{*} \\
(0.004)\end{array}$ & $\begin{array}{l}0.04^{*} \\
(0.004)\end{array}$ & $\begin{array}{l}0.02^{*} \\
(0.004)\end{array}$ & $\begin{array}{c}0.03^{*} \\
(0.005)\end{array}$ & $\begin{array}{l}0.00 \\
(0.003)\end{array}$ & $\begin{array}{c}0.01 \\
(0.004)\end{array}$ \\
\hline
\end{tabular}

Notes: ${ }^{*} p<0.05$.

Standard errors are in parentheses. Each coefficient is from a separate model. Coefficients from betweenwithin models are for the school-centered measure. All models include student- and school-level controls. Student-level controls: Cohort, sex, race, bilingual education status, FRPL status, neighborhood advantage, neighborhood disadvantage, age in third grade, age in third grade squared, and third grade test scores. School-level controls: racial composition, average FRPL status, average neighborhood advantage, average neighborhood disadvantage, average third grade test scores.

\section{Results}

\section{Associations between School Climate and Student Outcomes}

Table 5 presents the associations between the omnibus climate measures and student outcomes. For each outcome, I present the results from a regular school random effects model (in which no predictors are recentered) and a random effects "betweenwithin" model in which all predictors are centered on their school means. For test scores, I present fully standardized coefficients; for on-time ninth grade promotion and high school graduation, I present average marginal effects (AMEs). Supplement Table S.7 presents the associations between individual school climate measures and student outcomes. Because the data are populations and not random samples of CPS third-grade cohorts, I will not refer to the statistical significance of coefficients, although for the sake of comparison with other studies, tables include information on coefficients' standard errors and significance levels.

School climate measures have positive but modest associations with eighth grade test scores in both the regular and between-within random effects models. In fact, the coefficients for climate tend to be larger in the between-within model than in the regular random effects model. In the between-within models, a 1 SD increase in overall school climate is associated with students' eighth grade math and reading scores by 0.05 and $0.04 \mathrm{SD}$, respectively. If these associations are standardized using 
the standard deviations for within-school, intercohort variation presented in Table 4 , more impressive standardized coefficients of $0.15(0.05 * 0.67 / 0.22)$ for math and $0.19(0.04 * 0.67$ / 0.14) for reading are obtained.

The results for on-time ninth grade promotion are more disappointing. Overall climate, student climate, and teacher climate have virtually null associations with on-time ninth grade promotion.

The school climate measures also have minimal associations with high school graduation; all of the omnibus measures of climate have null associations in the regular random effects model. In the between-within model, the climate measures grow in magnitude, with AMEs of 0.01. As with test scores, these AMEs could be standardized to represent within-school, intercohort variation, producing effect sizes of $0.08(0.01 * 0.67 / 0.084)$ for overall climate, $0.09(0.01 * 0.74 / 0.084)$ for student climate, and $0.08(0.01 * 0.70 / 0.084)$ for teacher climate.

In the supplement, I relax the assumption that the associations between school climate and student outcomes are linear. The analyses show some minor nonlinear associations, particularly those between teacher climate measures and student test scores (improvement in teacher climate yields somewhat of a larger benefit for schools that tend to have weak teacher climate measures). I also test for the possibility that school climates experienced earlier in students' educational careers may matter more than those experienced in their later years and find no evidence for it. In addition, in the supplement I test for various threats to the conclusion that school climates have minimal-to-null associations with student outcomes. I find that this conclusion holds up even under alternative specifications addressing these threats.

\section{Are the Associations Moderated by Student Characteristics?}

It is possible that school organizational climate is stronger for some students than others. Lee, Smith, and Croninger (1997) argue that students from disadvantaged backgrounds are especially worse off when they attend schools characterized by impersonal student-teacher relations and low teacher expectations of students. Moller et al. (2013) also provide evidence that teacher professional communities are more beneficial for racial minority students and students of low socioeconomic status (SES). It is possible that the small or nonexistent associations between school climate and student outcomes shown thus far are an artifact of heterogeneity in climate's effects.

To test this possibility, I reran the between-within models, and in separate models I included interaction terms between the overall school climate measures with student sex, FRPL status, race, and third grade test scores. I present conditional associations in Table 6. There is not much evidence for Lee and Smith's (1997) and Moller et al.'s (2013) contentions that school climates especially matter for vulnerable students. To the extent there are differences in the associations, they tend to occur in favor of more advantaged students-the associations with overall climate are more positive for students who never received free or reduced price lunches (for test scores and graduation). 
Table 6: Associations between overall school climate and student outcomes, moderated by student characteristics.

\begin{tabular}{|c|c|c|c|c|}
\hline Moderator & $\begin{array}{c}(1) \\
\text { Ninth Grade } \\
\text { Promotion } \\
\text { (AMEs) }\end{array}$ & $\begin{array}{c}(2) \\
\text { Eighth Grade } \\
\text { Math } \\
\text { (betas) }\end{array}$ & $\begin{array}{c}(3) \\
\text { Eighth Grade } \\
\text { Reading } \\
\text { (betas) }\end{array}$ & $\begin{array}{l}\text { (4) } \\
\text { Graduation } \\
\text { (AMEs) }\end{array}$ \\
\hline Female Students & $\begin{array}{l}0.01^{*} \\
(0.003) \\
{[0.002} \\
0.015]\end{array}$ & $\begin{array}{l}0.06^{*} \\
(0.006) \\
{[0.049} \\
0.072]\end{array}$ & $\begin{array}{c}0.04^{*} \\
(0.006) \\
{[0.027} \\
0.052]\end{array}$ & $\begin{array}{l}0.01^{*} \\
(0.005) \\
{[0.001} \\
0.020]\end{array}$ \\
\hline Male Students & $\begin{array}{c}0.00 \\
(0.004) \\
{[-0.001} \\
0.005]\end{array}$ & $\begin{array}{l}0.04^{*} \\
(0.006) \\
{[0.029} \\
0.052]\end{array}$ & $\begin{array}{l}0.03^{*} \\
(0.006) \\
{[0.020} \\
0.045]\end{array}$ & $\begin{array}{c}0.01^{*} \\
(0.006) \\
{[-0.007} \\
0.017]\end{array}$ \\
\hline Asian/White Students & $\begin{array}{c}0.00 \\
(0.006) \\
{[-0.010} \\
0.013]\end{array}$ & $\begin{array}{l}0.06^{*} \\
(0.008) \\
{[0.049} \\
0.080]\end{array}$ & $\begin{array}{c}0.05^{*} \\
(0.009) \\
{[0.031} \\
0.065]\end{array}$ & $\begin{array}{c}0.02 \\
(0.008) \\
{[0.000} \\
0.030]\end{array}$ \\
\hline Black Students & $\begin{array}{c}0.00 \\
(0.003) \\
{[-0.005} \\
0.007]\end{array}$ & $\begin{array}{l}0.05^{*} \\
(0.005) \\
{[0.036} \\
0.056]\end{array}$ & $\begin{array}{l}0.03^{*} \\
(0.005) \\
{[0.021} \\
0.042]\end{array}$ & $\begin{array}{c}0.01 \\
(0.004) \\
{[-0.001} \\
0.016]\end{array}$ \\
\hline Latino Students & $\begin{array}{c}0.01 \\
(0.003) \\
{[-0.001} \\
0.011]\end{array}$ & $\begin{array}{l}0.05^{*} \\
(0.005) \\
{[0.040} \\
0.060]\end{array}$ & $\begin{array}{l}0.04^{*} \\
(0.006) \\
{[0.026} \\
0.048]\end{array}$ & $\begin{array}{c}0.01 \\
(0.005) \\
{[-0.002,} \\
0.016]\end{array}$ \\
\hline Never Received Free Lunches & $\begin{array}{c}0.00 \\
(0.006) \\
{[-0.011} \\
0.010]\end{array}$ & $\begin{array}{l}0.07^{*} \\
(0.008) \\
{[0.054} \\
0.086]\end{array}$ & $\begin{array}{c}0.04^{*} \\
(0.009) \\
{[0.026} \\
0.061]\end{array}$ & $\begin{array}{l}0.02^{*} \\
(0.007) \\
{[0.005} \\
0.032]\end{array}$ \\
\hline Always Received Free Lunches & $\begin{array}{c}0.00 \\
(0.003) \\
{[-0.002} \\
0.010]\end{array}$ & $\begin{array}{l}0.04^{*} \\
(0.005) \\
{[0.035} \\
0.054]\end{array}$ & $\begin{array}{c}0.03^{*} \\
(0.005) \\
{[0.023} \\
0.044]\end{array}$ & $\begin{array}{c}0.01 \\
(0.004) \\
{[-0.003} \\
0.014]\end{array}$ \\
\hline Third Grade Test Scores at 25th \%tile & $\begin{array}{c}0.00 \\
(0.004) \\
{[-0.004} \\
0.010]\end{array}$ & $\begin{array}{l}0.05^{*} \\
(0.005) \\
{[0.042} \\
0.060]\end{array}$ & $\begin{array}{c}0.04^{*} \\
(0.005) \\
{[0.030} \\
0.050]\end{array}$ & $\begin{array}{c}0.01 \\
(0.005) \\
{[-0.001} \\
0.017]\end{array}$ \\
\hline Third Grade Test Scores at 75th \%tile & $\begin{array}{c}0.00 \\
(0.002) \\
{[-0.003} \\
0.006]\end{array}$ & $\begin{array}{l}0.05^{*} \\
(0.005) \\
{[0.042} \\
0.062]\end{array}$ & $\begin{array}{l}0.04^{*} \\
(0.005) \\
{[0.031} \\
0.052]\end{array}$ & $\begin{array}{c}0.01 \\
(0.004) \\
{[-0.002} \\
0.013]\end{array}$ \\
\hline
\end{tabular}

Notes: ${ }^{*} p<0.05$.

Standard errors are in parentheses and 95 percent confidence intervals are in brackets. All coefficients are for the school-centered measures from separate between-within models. Models include all student- and school-level controls. 


\section{Conclusion}

Survey measures of schools' organizational practices and climates are common in educational research and they are diffusing into official educational statistics in various states and localities. Unfortunately, prior research has only just begun to go beyond controlling for observables when analyzing the associations of school climate with student outcomes. This study uses rich, longitudinal measures of school climate and rigorous methods to estimate associations between school climate and accumulated learning from third grade to eighth grade, students' on-time promotion to ninth grade, and high school graduation.

For advocates of measuring school climates and organizational practices using surveys, there is good news and there is bad news. The good news is that there are associations between school climate and accumulated student learning, and these associations are probably not an artifact of student selection into schools. Of course, it is impossible to rule out a scenario in which they are an artifact of an unmeasured, time-varying school-level confound, but given the rich school-level demographic controls used in this study, it seems unlikely.

The bad news is, first, these associations are fairly small. Second, they appear to be stronger for students who come from families with more resources (namely students who do not received free or reduced price lunches). The idea that improving school climates can help schools overcome the problems with disadvantaged student populations is not supported. Third, there is no association with on-time ninth grade promotion. Fourth, the fact that school climate has null to minimal associations with graduation and ninth grade promotion also casts doubt on the importance of the associations with test scores. What good is it to score 0.05 standard deviations higher on an eighth-grade test when a student is no more likely to be promoted to the ninth grade on time or graduate from high school?

The findings of this study have precedent in previous research showing small associations between school climate measures and test scores (Kraft et al. 2016; Ladd 2009; Sebastian and Allensworth 2012) and minimal to null associations with high school graduation outcomes (Bryk and Thum 1989; Reed 2015; Rumberger and Thomas 2000). Of these studies, Kraft et al.'s (2016) is the only one to leverage within-school variation in school climates; like this one, they found that isolating the within-school, over-time effects of school climate mattered little for the estimated effects.

Other studies have found more substantial effects on test scores, with effect sizes exceeding 0.20 (Goddard et al. 2015; Hallinger and Heck 2010; Ronfeldt et al. 2015). This study notably contradicts the findings of two prior studies using data on CPS schools. A brief appendix in Bryk et al. (2010:250-251) used the same climate measures as this study and a similar time range in Chicago (1997-2005), and found large between- and within-school effects of school climate measures (exceeding standardized coefficients of 0.30 and 0.10 , respectively) on school's value-add to test scores. While these studies used careful designs, either controlling for prior achievement or looking at students' achievement trajectories, I speculate their large effect sizes are due to a combination of (a) having the school as the unit of analysis and thus inflating effect sizes by removing within-school, between-student variation 
from the outcome and (b) measurement error in their control variables for student SES. I went to some length to minimize measurement error in SES by controlling for both FRPL status and students' block group characteristics as well as making both variables averages across all years each student was in CPS.

Additonally, a report by this author (Klugman et al. 2015) found that school climate measures had strong associations with graduation rates in CPS high schools (but not in other Illinois public high schools). That report used only school-level, cross-sectional data and could not include the student-level covariates related to prior achievement that I controlled for in this study.

Some sociologists argue that attacking inequalities among families is the only viable route to ameliorating educational inequalities (e.g., Downey and Condron 2016). Like the results of Jennings et al. (2015), my findings indicate that this argument is too quick to give up on school improvement, given that schools' student outcomes do change substantially over time in ways that are not reducible to changing demographics (Table 4). However, this study's main conclusion is that assessing schools' organizational practices and climates using surveys is not a feasible means to achieve school improvement.

There are two possible interpretations of this finding. One, the sociological insight that relationships among school actors influence the technical core of schoolsinstruction-and thus student outcomes is correct, but surveys, for all of their practicality and economy, cannot capture the quality of these relationships with much precision.

Two, the measures are sufficiently precise, but the sociological contention about school relationships is overstated. Schools are "loosely coupled" systems (Weick 1976), so the quality of teachers' work is dependent just on their individual efforts to convey knowledge to students and inspire them to meet high academic standards (Lortie 1977). Broader sets of relationships, beyond that of the student-teacher in the classroom, are just not consequential for school productivity.

This study cannot adjudicate between these two scenarios, but there are reasons for according more weight to imprecise survey measures than to the loose coupling scenario. There is evidence that interventions focusing on improving relationships among teachers and administrators is consequential for school improvement (Borman et al. 2003; Cook, Murphy, and Hunt 2000). Notably, Cook et al. (2000) found that in Chicago, the Comer School Development Program, which targets relationships among teachers and administrators, was efficacious in improving student outcomes and survey reports of certain aspects of school climate, but improved school climate did not explain the improvement in student outcomes-in other words, the Comer schools seeing improved outcomes did not see improved survey reports of school climate, and vice versa.

The loose coupling scenario focusing on the individual efforts of teachers is arguing that aggregated survey reports capturing different concepts, those related to teachers' efforts in the classroom, should affect student outcomes. For instance, the Consortium has deployed new survey questions administered to students, asking them about their schools' academic press (Murphy et al. 1982) as well as the pedagogical techniques used in their classes. Unfortunately, they were not 
deployed consistently through this study's time frame and could not be used in these analyses. Surely they would matter more for student outcomes?

This is doubtful. It is striking that for all of the Consortium's attempts to capture distinct aspects of school organization, their different measures end up having similar associations with outcomes (as shown in Table S.7 in the online supplement). This is consistent with a scenario that survey reports are based on teachers' and students' global sense of how well the school is doing. In that case, it is unlikely there is some missing concept that needs to be uncovered to show strong climate effects.

It is customary for social science articles to conclude with calls for more research. And indeed, confirmation or disconfirmation of this study's findings should be pursued (and can be easily achieved with existing data). But if the findings are confirmed, the major efforts to collect and analyze school climate data undertaken by districts, states, various not-for-profit and for-profit entities, as well as the time taken by students and teachers to complete the questionnaires, have been wasteful and should cease.

\section{Notes}

1 In the 1997 survey, student surveys were administered only to students in the sixth, eighth, and tenth grades.

2 The ITBS was administered from 1989-1990 to 2004-2005, the original ISAT test was administered from 1998-1999 to 2004-2005, and the post-No Child Left Behind (NCLB) version of the ISAT was administered from 2005-2006 to 2013-2014. A majority (55 percent) of students took the post-NCLB ISAT in the eighth grade; 45 percent of students took the ITBS and the pre-NCLB ISAT test. A very small number of students $(0.01$ percent) took the Northwest Evaluation Association Measure of Academic Progress that was introduced in 2013-2014 and was intended to replace the ISAT.

3 The New York City Department of Education administers school climate surveys to students and teachers based on the Consortium's surveys, and analysts of that data argue for a singular, global measure of school climate akin to the ones used here (Nathanson et al., 2013).

4 Note the potential for measurement error in the student measures for K-8 schools: these measures are based on reports by students in grades $6-8$ to characterize the climate experienced by all students. However, this problem should be obviated by analyzing students in grades 4-8. And as will be seen, the effects of student climate measured in later years are only trivially larger than those of student climate measured in the fourth grade.

5 In alternative specifications (not shown), I used a weighted average of the three years of climate measures, with the weights determined by an exponential decay function used by Moller et al. (2013). I experimented with decay rates of 25, 50, and 75 percent (that to varying degrees underweight the fourth and sixth year measures) and found the results very similar to those presented here.

6 Nearly 40 percent of students' third grade scores came from the ITBS alone, 46 percent of scores came from the ITBS and the pre-NCLB ISAT, and the remaining 14 percent came from the post-NCLB ISAT. 
7 Unfortunately, the between-within method introduces a modest amount of bias in logistic regressions (Allison 2014; Brumback et al. 2010; Goetgeluk and Vansteelandt 2008). Per Allison's (2014) advice, I checked for this bias by comparing the between-within results to another between-within model with added controls for the squared and cubic terms of the school means for all predictors, as well as the school standard deviation of all predictors. The results are nearly identical, indicating bias is not a concern.

8 Multilevel linear probability models were run for the dichotomous outcomes of ontime ninth grade promotion and high school graduation for the sake of having easily interpretable standard deviations and intraclass correlations.

\section{References}

Allison, Paul D. 2009. Fixed Effects Regression Models. Los Angeles, CA: Sage Publications. https://doi.org/10.4135/9781412993869

Allison, Paul D. 2014. "Problems with the Hybrid Method." Statistical Horizons. Retrieved July 30, 2016. http://statisticalhorizons.com/problems-with-the-hybrid-method

Blad, Evie. 2016. "ESSA Law Broadens Definition of School Success." Education Week, January 5. Retrieved May 2, 2016 (http://www.edweek.org/ew/articles/2016/01/ 06/essa-law-broadens-definition-of-school-success . html?qs=esea+school+ climate).

Bodovski, Katerina, Inbal Nahum-Shani, and Rachael Walsh. 2013. "School Climate and Students' Early Mathematics Learning: Another Search for Contextual Effects." American Journal of Education 119(2):209-34. http://dx . doi .org/10.1086/667227

Bond, Trevor G., and Christine M. Fox. 2015. Applying the Rasch Model: Fundamental Measurement in the Human Sciences. New York: Routledge.

Borman, Geoffrey D., Gina M. Hewes, Laura T. Overman, and Shelly Brown. 2003. "Comprehensive School Reform and Achievement: A Meta-Analysis." Review of Educational Research 73(2):125-230. http://dx.doi.org/10.3102/00346543073002125

Brumback, Babette A., Amy B. Dailey, Lyndia Brumback, Melvin D. Livingston, and Zhulin He. 2010. "Adjusting for Confounding by Cluster Using Generalized Linear Mixed Models." Statistics E Probability Letters 80(21-22):1650-54. http://dx .doi .org/10.1016/ j.spl.2010.07.006

Bryk, Anthony S., and Barbara Schneider. 2002. Trust in Schools: A Core Resource For Improvement. New York: Russell Sage Foundation.

Bryk, Anthony S., Penny Bender Sebring, Elaine Allensworth, Stuart Luppescu, and John Q. Easton. 2010. Organizing Schools For Improvement: Lessons From Chicago. Chicago, IL: University of Chicago Press.

Bryk, Anthony S., and Yeow Meng Thum. 1989. "The Effects of High School Organization on Dropping Out: An Exploratory Investigation." American Educational Research Journal 26(3):353-83. http://dx.doi.org/10.3102/00028312026003353

Burtless, Gary, ed. 1996. Does Money Matter? The Effect of School Resources on Student Achievement and Adult Success. Washington, DC: Brookings Institution Press.

Coleman, James S., Ernest Q. Campbell, Carol J. Hobson, James McPartland, Alexander M. Mood, Frederic D. Weinfeld, and Robert L. York. 1966. Equality of Educational Opportunity. Washington, DC: U.S. Government Printing Office. 
Cook, Thomas D., Robert F. Murphy, and H. David Hunt. 2000. "Comer's School Development Program in Chicago: A Theory-Based Evaluation." American Educational Research Journal 37(2):535-97. http://dx.doi .org/10 .3102/00028312037002535

Downey, Douglas B., and Dennis J. Condron. 2016."Fifty Years Since the Coleman Report: Rethinking the Relationship between Schools and Inequality." Sociology of Education 89(3):207-20. http://dx.doi .org/10.1177/0038040716651676

Gamoran, Adam. 1987. "The Stratification of High School Learning Opportunities." Sociology of Education 60:135-55. http://dx.doi .org/10.2307/2112271

Gamoran, Adam, Ana Cristina Collares, and Sarah Barfels. 2016. "Does Racial Isolation in School Lead to Long-Term Disadvantages? Labor Market Consequences of High School Racial Composition." American Journal of Sociology 121(4):1116-67. http://dx. doi .org/ $10.1086 / 683605$

Gamoran, Adam, Walter G. Secada, and Cora B. Marrett. 2000. "The Organizational Context or Teaching and Learning: Changing Theoretical Perspectives." Pp. 37-63 in Handbook of the Sociology of Education, edited by M. Hallinan. New York: Kluwer Academic/Plenum Publishers.

Goddard, Roger D., Yvonne L. Goddard, Eun Sook Kim, and Robert Miller. 2015. "A Theoretical and Empirical Analysis of the Roles of Instructional Leadership, Teacher Collaboration, and Collective Efficacy Beliefs in Support of Student Learning." American Journal of Education 121(4):501-30. http://dx . doi .org/10.1086/681925

Goetgeluk, Sylvie, and Stign Vansteelandt. 2008. "Conditional Generalized Estimating Equations for the Analysis of Clustered and Longitudinal Data." Biometrics 64(3):772-80. http://dx.doi.org/10.1111/j.1541-0420.2007.00944.x

Grubb, W. Norton. 2009. The Money Myth: School Resources, Outcomes, and Equity. New York: Russell Sage Foundation.

Hallinger, Philip, Leonard Bickman, and Ken Davis. 1996. "School Context, Principal Leadership, and Student Reading Achievement." Elementary School Journal 96(5):527-49. http://dx.doi.org/10.1086/461843

Hallinger, Philip and Ronald H. Heck. 2010. "Leadership for Learning: Does Collaborative Leadership Make a Difference in School Improvement?" Educational Management Administration E Leadership 38(6):654-78. http://dx . doi . org/10 .1177/1741143210379060

Heck, Ronald H. and Philip Hallinger. 2009. "Assessing the Contribution of Distributed Leadership to School Improvement and Growth in Math Achievement." American Educational Research Journal 46(3):659-89. http://dx . doi .org/10.3102/0002831209340042

Heckman, James J., Rodrigo Pinto, and Peter Savelyev. 2014. "Understanding the Mechanisms Through Which An Influential Early Childhood Program Boosted Adult Outcomes." American Economic Review 103:2052-86. http://dx. doi .org/10.1257/aer.103.6. 2052

Hitt, Dallas Hambrick, and Pamela D. Tucker. 2016. "Systematic Review of Key Leader Practices Found to Influence Student Achievement: A Unified Framework." Review of Educational Research 86(2): 531-569. http://dx.doi.org/10.3102/0034654315614911

Jackson, C. Kirabo. 2012. "Non-Cognitive Ability, Test Scores, and Teacher Quality: Evidence from 9th Grade Teachers in North Carolina." NBER Working Paper No. 18624. Retrieved November 21st, 2016. http: //www . nber . org/papers/w18624

Jackson, C. Kirabo, Rucker C. Johnson, and Claudia Persico. 2016. "The Effects of School Spending on Educational And Economic Outcomes: Evidence from School Finance Reforms." Quarterly Journal of Economics 131(1):157-218. http://dx . doi .org/10.1093/ qje/qjv036 
Jennings, Jennifer L., David Deming, Christopher Jencks, Maya Lopuch, and Beth Schueler. 2015. "Do Differences in School Quality Matter More Than We Thought? New Evidence on Educational Opportunity in the Twenty-First Century." Sociology of Education 88(1):5682. http://dx.doi.org/10.1177/0038040714562006

Johnson, Susan M., Matthew A. Kraft, and John P. Papay. 2012. "How Context Matters in High-Need Schools: The Effects of Teachers' Working Conditions on Their Professional Satisfaction and Their Students' Achievement." Teachers College Record 114:1-39. http: //www . tcrecord. org/content. asp? contentid=16685

Klugman, Joshua, Molly F. Gordon, Penny Bender Sebring, and Susan E. Sporte. 2015. A First Look at the 5Essentials in Illinois Schools. Chicago, IL: University of Chicago Consortium on School Research. Retrieved November 20, 2016. http://consortium. uchicago.edu/ sites/default/files/publications/Statewide\%205E\%20Report.pdf

Kotok, Stephen, Sakiko Ikoma, and Katerina Bodovski. 2016. "School Climate and Dropping Out of School in the Era of Accountability." American Journal of Education 122. http: //dx.doi.org/10.1086/687275

Kraft, Matthew A., William H. Marinell, and Darrick Shan-Wei Yee. 2016. "School Organizational Contexts, Teacher Turnover, and Student Achievement: Evidence From Panel Data." American Educational Research Journal 53(5):1411-49. http://dx . doi .org/10 .3102/ 0002831216667478

Ladd, Helen. 2009. Teachers' Perceptions of Their Working Conditions: How Predictive of PolicyRelevant Outcomes? Washington, DC: Urban Institute.

Lauen, Douglas Lee, and S. Michael Gaddis. 2013. "Exposure to Classroom Poverty and Test Score Achievement: Contextual Effects or Selection?" American Journal of Sociology 118(4):94-79. http://dx.doi.org/10.1086/668408

Lee, Valerie E., and Julia B. Smith. 1993. "Effects of School Restructuring on the Achievement and Engagement of Middle-Grade Students." Sociology of Education 66:164-87. http: //dx.doi.org/10.2307/2112735

Lee, Valerie E., Julia B. Smith, and Robert G. Croninger. 1997. "How High School Organization Influences the Equitable Distribution of Learning in Mathematics and Science." Sociology of Education 70(2):128-50. http://dx.doi .org/10.2307/2673160

Lortie, Dan C. 1977. Schoolteacher: A Sociological Study. Chicago, IL: University of Chicago Press.

Marks, Helen M., and Susan M. Printy. 2003. "Principal Leadership and School Performance: An Integration of Transformational and Instructional Leadership." Educational Administration Quarterly 39(3):370-97. http://dx . doi .org/10.1177/0013161X03253412

Moller, Stephanie, Roslyn Arlin Mickelson, Elizabeth Stearns, Neena Banerjee, and Martha Cecilia Bottia. 2013. "Collective Pedagogical Teacher Culture and Mathematics Achievement: Differences By Race, Ethnicity, and Socioeconomic Status." Sociology of Education 86(2):174-94. http://dx.doi.org/10.1177/0038040712472911

Murphy, Joseph F., Marsha Weil, Philip Hallinger, and Alexis Mitman. 1982. "Academic Press: Translating High Expectations Into School Policies and Classroom Practices." Educational Leadership 40(3):22-26.

Nathanson, Lori, Rachel Cole, James J. Kemple, Jessica Lent, Meghan McCormick, and Micha Segeritz. 2013. New York City School Survey: 2008-2010: Assessing the Reliability and Validity of a Progress Report Measure. New York: Research Alliance for New York City Schools. Retrieved November 15, 2016. http://steinhardt.nyu. edu/scmsAdmin/media/users/ sg158/PDFs/school_survey/NYCSchoolSurvey_AssessingReliabilityValidity.pdf 
Pallas, Aaron M. 1988. "School Climate in American High Schools." Teachers College Record 89(4):541-54. http: //www. tcrecord. org/content. asp? contentid=543

Phillips, Meredith. 1997. "What Makes Schools Effective? A Comparison of the Relationships of Communitarian Climate and Academic Climate to Mathematics Achievement and Attendance During Middle Schools." American Educational Research Journal 34(4):633-62. http://dx.doi.org/10.3102/00028312034004633

Raudenbush, Stephen W., and Anthony S. Bryk. 2002. Hierarchical Linear Models: Applications and Data Analysis. 2nd ed. Thousand Oaks, CA: Sage Publications.

Reed, Katherine. 2015. "School Incorporation and High School Completion among Latino Youth." American Journal of Education 121(3):347-79. http://dx . doi .org/10.1086/ 680408

Ronfeldt, Matthew, Susanna Owens Farmer, Kiel McQueen, and Jason A. Grissom. 2015. "Teacher Collaboration in Instructional Teams and Student Achievement." American Educational Research Journal 52(3):475-514. http://dx . doi .org/10.3102/0002831215585562

Rumberger, Russell W. and Scott L. Thomas. 2000. "The Distribution of Dropout and Turnover Rates Among Urban and Suburban High Schools." Sociology of Education 73(1):39-67. http://dx.doi.org/10.2307/2673198

Sebastian, James, and Elaine Allensworth. 2012. "The Influence of Principal Leadership on Classroom Instruction and Student Learning: A Study of Mediated Pathways to Learning." Educational Administration Quarterly 48(4):626-63. http://dx.doi.org/10 . $1177 / 0013161 \mathrm{X} 11436273$

Sebring, Penny Bender, Elaine Allensworth, Anthony S. Bryk, John Q. Easton, and Stuart Luppescu. 2006. The Essential Supports for School Improvement. Chicago, IL: Consortium on Chicago School Research. Retrieved November 21, 2016. https ://consortium. uchicago.edu/publications/essential-supports-school-improvement

Sjölander, Arvid, Paul Lichtenstein, Henrik Larsson, and Yudi Pawitan. 2013. "Betweenwithin Models for Survival Analysis." Statistics in Medicine 32:3067-76. http://dx. doi . org/10.1002/sim. 5767

Weick, Karl. 1976. "Educational Organizations as Loosely Coupled Systems." Administrative Science Quarterly 21:1-19. http://dx . doi .org/10.2307/2391875 
Acknowledgements: The author thanks Elaine Allensworth, Kaleen Healey, Paul Moore, Eliza Moeller, Stephen Morgan, Shanette Porter, Lauren Sartain, and Penny Bender Sebring for valuable comments on previous drafts of this article. The author is also grateful to the University of Chicago Consortium on School Research for letting him conduct his analyses on their server.

Conflicts of Interest Disclosure: While working on this study, the author was employed by the University of Chicago Consortium on School Research (which developed the survey measures discussed here) and for part of the time was funded by the LewisSebring Family Foundation. Cofounder Charles Lewis sits on the board of the nonprofit organization UChicago-Impact, a sister organization of the Consortium that sells its services administering the school climate measures used in this study (branded as the "5Essentials"). Cofounder Penny Sebring is a director of the Consortium and, before the advent of UChicago-Impact, has authored studies arguing the school climate measures are beneficial for school improvement. Sebring was given an early draft of this study, but the author had final say over analyses and conclusions. The views expressed in this study are those of the author and the author alone.

Data Availability and Replication: Because of data security issues, only Consortium staff have access to this study's data. Syntax files producing these analyses are available at http://sites.temple.edu/klugman/curriculum-vitae/essential-supports/.

Joshua Klugman: Department of Sociology, Temple University.

E-mail: klugman@temple.edu. 